$\xi=-1$

\title{
Coconut Coir Experimental Process for Producing an Alternative Block Toy Compound
}

\author{
Saiful Bahari Mohd Yusoff ${ }^{1 *}$, Sinin Hamdan ${ }^{1}$, Zalina Ibrahim ${ }^{2}$, Shah Jhihan Abdullah ${ }^{3}$ \\ ${ }^{1}$ Institute of Design and Innovation, Universiti Malaysia Sarawak \\ ${ }^{2}$ Faculty of Business and Management, Universiti Teknologi MARA (UiTM) Sarawak \\ ${ }^{3}$ Faculty of Applied and Creative Arts, Universiti Malaysia Sarawak \\ *Corresponding author E-mail: mysaiful@unimas.my
}

\begin{abstract}
Currently, children's block toys use solid wood, processed wood and Medium-Density Fiber board (MDF). MDF is a mixture of sawdust that is held together with wax, resin and formaldehyde and has been widely used to produce children's toys. MDF are heavy and found to be health hazardous especially to children. This research focuses on the process of transforming the waste from the coconut coir/husk as an alternative to the current unsafe materials into toy block. The coconut coir/husk is creatively processed to produce children toy block that are soft, lightweight, cheap, harmless for children to use and environmental friendly. The process involved treatment of insignificant waste and transforming it into a competitive product, thus reducing mass pollution by the coconut farmers and open burning of coconut coir/husks.
\end{abstract}

Keywords: Coconut coir; Coconut husk; Children block toy.

\section{Introduction}

Coconut tree is commonly known to make many products. In the book of "Replanting the Tree of Life, towards an International Agenda for Coconut Palm Research" [1], stated that coconut tree has many functions and acts as an important tree to the local people. According to [1], the coconut tree is named "the Tree of Life" because almost every part of the coconut tree can be used to make precious products for the locals.

Research based on coconut studies had been done in many countries to seek the potential usage of coconut tree [2-3]. Apart from the many usage of the coconut tree, many research also ventured into a more scientific studies to help increase the versatility of the coconut tree especially the coconut coir/husk. [4] looked at the production process of coir and coir products; [5] experimented coconut peat to find alternative artificial soil ingredient for the earthworm toxicity testing. [6] investigated the use of Coco Coir Polypropylene as thermal insulator and [7] developed paper using coir fibers as a product packaging.

In Malaysia, coconut coir/husk is mostly considered useless and are usually thrown out by coconut farmers. Farmers dispose coconut coir by burning which resulted in the air pollution. One of the efforts to fully utilize the unwanted coconut coir is processing the coir/husk into useful material that can be commercialized and produced an alternative material for children's toy block. Many children's toys heavily depend on wood material, processed wood and dangerous substances like MDF. The use of these substances can affect children safety factor due to the nature of the material is too hard and heavy. Even though there are many research conducted on coconut coir/husk, the experimentation on the potential of coconut coir/husk as a softer and safer block toys for children have yet to be ventured. Therefore, a material from coconut coir/husk is proposed using a simple and cost saving process.

\section{Materials and Method}

The materials involved are only coconut coir/husk, boric acid, latex and formic acid. The coconut coir/husk were obtained from Borneo Coconut Fiber Sdn Bhd in Asajaya. Methods used in this process are based on a standard practice whereby boric acid is used to prevent the coconut coir/husk from fungal infection and termites.

A few stages involved in the processing of the coconut coir/husk into the toy compound. The first stage is the processing of the raw material which are divided into the treatment of the coconut coir/husk and the treatment of the coir fiber. The final process is the process in producing the new material for the block toy.

Figure 1 below is the experiment flowchart of how the coconut coir/husk is processed into the block toy.

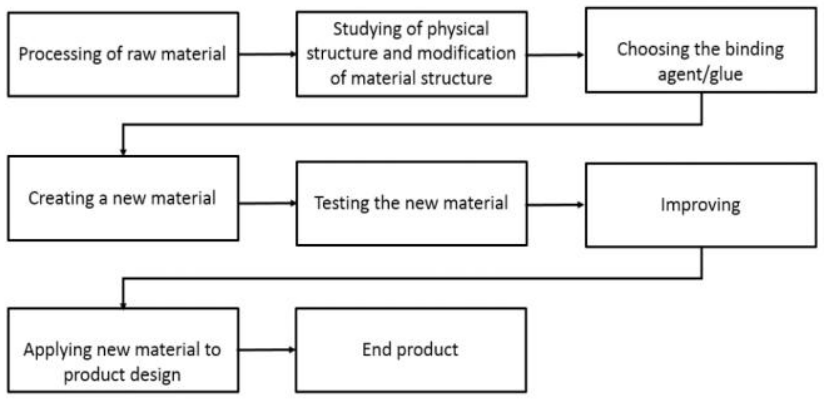

Fig. 1: Experiment flowchart 


\subsection{Processing the Raw Material}

The experiment began with the processing of raw material. At this stage, it is important to make sure that the coconut coir/husk to go through the drying process before moving to other stages in order to avoid poor treatment process such as shortened shelf life of coconut coir/husk due to fungal infection, termites and decomposition, foul smell that may produce from coconut coir/husk, and the coconut coir/husk may become the breeding home of ants and termites.

\subsection{Treatment Process of Coconut Coir/Husk}

The first treatment process for coconut coir/husk uses the boric acid solution (see Figure 2). Boric acid is used to avoid fungal infection and termites from attacking the coconut coir/husk. The coconut coir/husk is soaked for several days to ensure full absorption of boric acid. After the soaking stage, the coconut coir/husk is dried using a multipurpose oven at medium temperature for several hours. The coconut coir/husk is later left dried at room temperature until fully dried. This drying process is long as coconut coir/husk contains high content of water

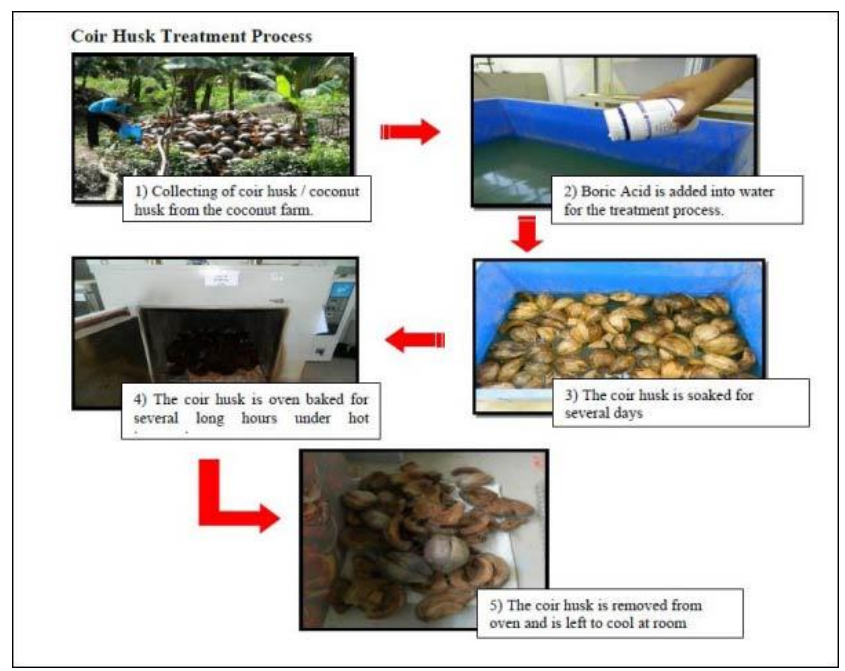

Fig. 2: First stage of treatment process

\subsection{Treatment Process of Coir Fiber}

The second treatment process for coconut coir/husk goes through the processing mill to create the coir fiber (Figure 3). Separation is done by sifting the material into coir fiber and coir dust. Coir fiber is then added with Boric Acid solution. The soaked coir fiber is later transferred onto a towel and dried using a dryer to remove the any water. After that, the coir fiber is left to dry under the sun until it is completely dried.

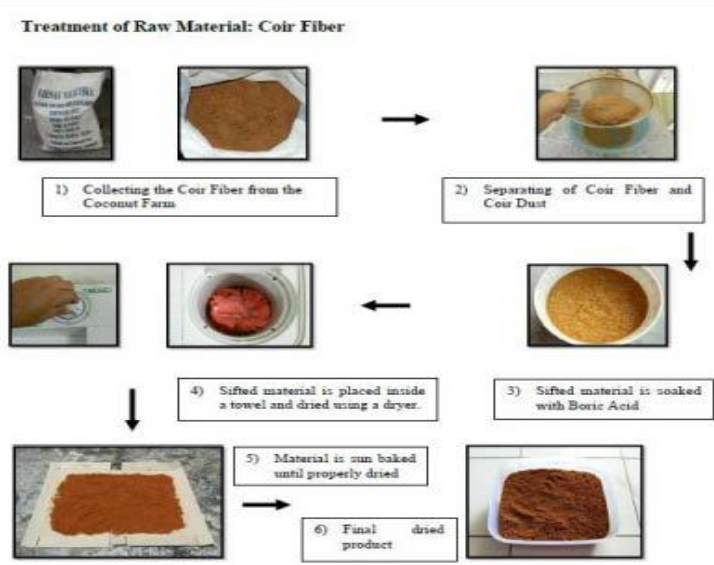

\subsection{Process in Producing the New Material for Block Toy}

Coir Fiber is added with latex that is mixed with formic acid and water (Figure 4). Latex contains complex emulsion such as protein, alkaloid, starch, sugar, oil, tanine, resin, and gum that will become solid when exposed to air. All the ingredients are mixed together thoroughly. Due to the nature of the fiber, a binding agent is needed to produce a new product. To ensure that the end products are environmentally friendly, the material used to create the block toy uses $95 \%$ natural ingredients.

The mixture is then poured into a metal container and manually compressed using a compress machine. The mixture is then left to allow it to become hard. This mixture is left to dry at room temperature. Once the mixture is dried and removed from the metal container, the product found to be light, soft, rubbery and shaped according to the mould. To ensure the quality of the product, the end product is tested against the pressure resistance, termite resistance water resistance.

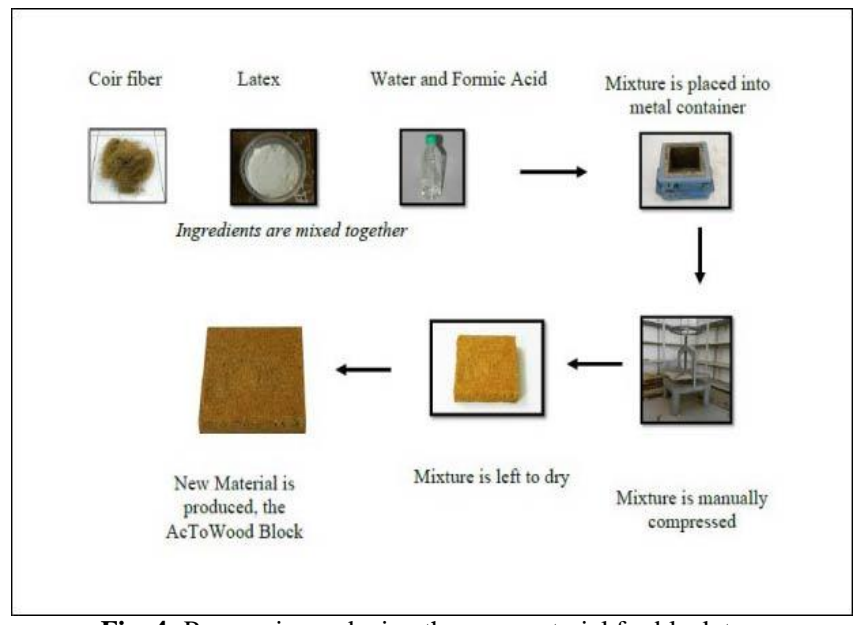

Fig. 4: Process in producing the new material for block toy

\section{Results and Discussion}

The results in the Figure 5 below shows nine samples were derived from the experiment to produce the toy block. Each sample contained different types of material. It was found that Sample 5 and Sample 6 to be the most suitable sample for the pressure resistance, termite resistance water resistance testing.

\begin{tabular}{|c|c|c|}
\hline Material & Result & Outpur \\
\hline $\begin{array}{l}\text { Sample } 1 \\
\text { 1. Cocopeat } 5 \mathrm{~g} \\
\text { 2. Latex } 300 \mathrm{ml}\end{array}$ & $\begin{array}{l}\text { Rubbery and stick to mosaic floor } \\
\text { Early experiment produced foul latex smell and throughout } \\
\text { drying process } \\
\text { Infestation of mold after drying } \\
\text { Can be cut using knife } \\
\text { Over drying can transformed sample into black and sticky } \\
\text { Non absorb } \\
\text { Flammable }\end{array}$ & 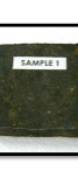 \\
\hline Material & Result & Output \\
\hline $\begin{array}{l}\text { Sample } 2 \\
\text { 1. Cocopeat } 170 \mathrm{~g} \\
\text { 2. Latex } 200 \mathrm{ml} \\
\text { 3. Water } 150 \mathrm{ml} \\
\text { 4. Formic acid } 3 \text { drops }\end{array}$ & $\begin{array}{l}\text { Mixture formed after } 20 \text { minutes } \\
\text { Output is light and soft } \\
\text { Slight crack during removal from mold container } \\
\text { Breakable output } \\
\text { Can be cut using knife }\end{array}$ & उАजिय2 \\
\hline Material & Result & Output \\
\hline $\begin{array}{l}\text { Sample } 3 \\
\text { 1. Cocopeat } 170 \mathrm{~g} \\
\text { 2. Latex } 175 \mathrm{ml} \\
\text { 3. Water } 80 \mathrm{ml} \\
\text { 4. Formic acid } 3 \text { drops }\end{array}$ & $\begin{array}{l}\text { Rubbery and stick to mosaic floor } \\
\text { Output is light and soft } \\
\text { Do not crack during removal from mold container } \\
\text { Can be cut using knife }\end{array}$ & Duwas \\
\hline
\end{tabular}

Fig. 5: Results from the testing output 


\begin{tabular}{|c|c|c|}
\hline Material & Result & Output \\
\hline $\begin{array}{l}\text { Sample } 4 \\
\text { 1. Cocopeat } 170 \mathrm{~g} \\
\text { 2. Latex } 200 \mathrm{ml} \\
\text { 3. Water } 150 \mathrm{ml} \\
\text { 4. Formic acid } 3 \text { drops }\end{array}$ & $\begin{array}{l}\text { Rubbery and stick to mosaic floor } \\
\text { Output is light and soft } \\
\text { Mixture formed after } 20 \text { minutes } \\
\text { Do not crack during removal from mold container } \\
\text { Can be cut using knife }\end{array}$ & $\operatorname{man}$ \\
\hline Material & Result & Output \\
\hline $\begin{array}{l}\text { Sample } 5 \\
\text { 1. Cocopeat } 120 \mathrm{~g} \\
\text { 2. Latex } 150 \mathrm{ml} \\
\text { 3. Water } 50 \mathrm{ml} \\
\text { 4. Formic acid } 3 \text { drops }\end{array}$ & $\begin{array}{l}\text { Rubbery and stick to mosaic floor } \\
\text { Output is light and soft } \\
\text { Mixture formed after } 20 \text { minutes } \\
\text { Do not crack during removal from mold container } \\
\text { Can be cut using knife }\end{array}$ & एक्या \\
\hline Material & Result & Output \\
\hline $\begin{array}{l}\text { Sample } 6 \\
\text { 1. Cocopeat } 170 \mathrm{~g} \\
\text { 2. Latex } 150 \mathrm{ml} \\
\text { 3. Water } 75 \mathrm{ml} \\
\text { 4. Formic acid } 3 \text { drops }\end{array}$ & $\begin{array}{l}\text { Rubbery and stick to mosaic floor } \\
\text { Output is light and soft } \\
\text { Mixture formed after } 20 \text { minutes } \\
\text { Do not crack during removal from mold container } \\
\text { Can be cut using knife }\end{array}$ & एख़ा \\
\hline Material & Result & Output \\
\hline $\begin{array}{l}\text { Sample } 7 \\
\text { 1. Cocopeat } 200 \mathrm{~g} \\
\text { 2. Latex } 175 \mathrm{ml} \\
\text { 3. Water } 70 \mathrm{ml} \\
\text { 4. Formic acid } 2 \text { drops }\end{array}$ & $\begin{array}{l}\text { Rubbery and stick to mosaic floor } \\
\text { Output is light and soft } \\
\text { Mixture formed after } 25 \text { minutes } \\
\text { Do not crack during removal from mold container } \\
\text { Can be cut using knife }\end{array}$ & 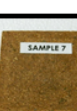 \\
\hline Material & Result & Output \\
\hline $\begin{array}{l}\text { Sample } 8 \\
\text { 1. Cocopeat } 210 \mathrm{~g} \\
\text { 2. Latex } 170 \mathrm{ml} \\
\text { 3. Water } 65 \mathrm{ml}\end{array}$ & $\begin{array}{l}\text { Rubbery and stick to mosaic floor } \\
\text { Output is light and soft } \\
\text { Mixture formed after } 60 \text { minutes } \\
\text { Do not crack during removal from mold container } \\
\text { Can be easily cut using knife } \\
\text { Has surface texture }\end{array}$ & 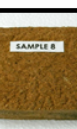 \\
\hline Material & Result & Output \\
\hline $\begin{array}{l}\text { Sample } 9 \\
\text { 1. Cocopeat } 230 \mathrm{~g} \\
\text { 2. Latex } 175 \mathrm{ml} \\
\text { 3. Water } 75 \mathrm{ml}\end{array}$ & $\begin{array}{l}\text { Rubbery and stick to mosaic floor } \\
\text { Output is light and soft } \\
\text { Mixture formed after } 60 \text { minutes } \\
\text { Do not crack during removal from mold container } \\
\text { Can be easily cut using knife } \\
\text { Has surface texture }\end{array}$ & вимит \\
\hline
\end{tabular}

Fig. 5: Continued

Sample 3 to Sample 9 were selected to go through pressure resistance testing. Only Sample 5 and Sample 6 could stand higher pressure. However, Sample 5 provided a better result than Sample 6 . Tables 1 and 2 show the thickness, width and height only received minor effect after the pressure resistance test. Even though Sample 5 has received a pressure test up to $5500 \mathrm{~kg}$, the Sample 5 can still withstand the pressure.

Table 1: Result from the pressure testing

\begin{tabular}{cccc}
\hline Sample 5 & Thickness $(\mathbf{m m})$ & Width $(\mathbf{m m})$ & Height $(\mathbf{m m})$ \\
\hline Before & 25 & 98 & 98 \\
After & 10 & 100.3 & 100.5 \\
\hline
\end{tabular}

Table 2: Final result from the pressure testing and total pressure used

\begin{tabular}{|c|c|c|c|}
\hline Time (s) & Stroke $(\mathrm{mm})$ & Force $(\mathrm{kN})$ & $5391 \times 10^{3}$ \\
\hline 136.3 & 22.7 & 53.91 & 50.81 \\
\hline
\end{tabular}

Termite resistance test was also conducted by placing the Sample 5 that has been given wood treatment into a black dustbin filled with termites and rotten wood. Weekly observation was conducted for a period of four weeks. From the Table 3, it can be seen that termites were not interested with the Sample 5 and surrounded only the rotten wood. By week 4, Sample 5 was still in good condition and termites were all dead.
Table 3: Final result from the termites testing

\begin{tabular}{|c|c|}
\hline Observation Duration & Result \\
\hline Week 1 & $\begin{array}{l}\text { 1. No damage to sample } \\
\text { 2. Termites focussed at the rotten wood }\end{array}$ \\
\hline Week 2 & $\begin{array}{l}\text { 1. No damage to sample } \\
\text { 2. Termites were not near sample. }\end{array}$ \\
\hline Week 3 & $\begin{array}{l}\text { 1. No damage to sample } \\
\text { 2. Termites were not near sample }\end{array}$ \\
\hline Week 4 & $\begin{array}{l}\text { 1. No damage to sample } \\
\text { 2. Termites were all dead }\end{array}$ \\
\hline
\end{tabular}

For the water absorption testing, Sample 5 was divided into two. One sample is without rubber coating $(247 \mathrm{~g})$ and another is painted with a thin layer of rubber coating $(385 \mathrm{~g})$. Each sample was tested for 600 minutes inside a container filled with 4 liters of water. From Figure 6, it can be seen that the sample without rubber coating has higher water absorption level (total of $121 \mathrm{ml}$ ) compared to the sample with rubber coating (total of $98 \mathrm{ml}$ ).
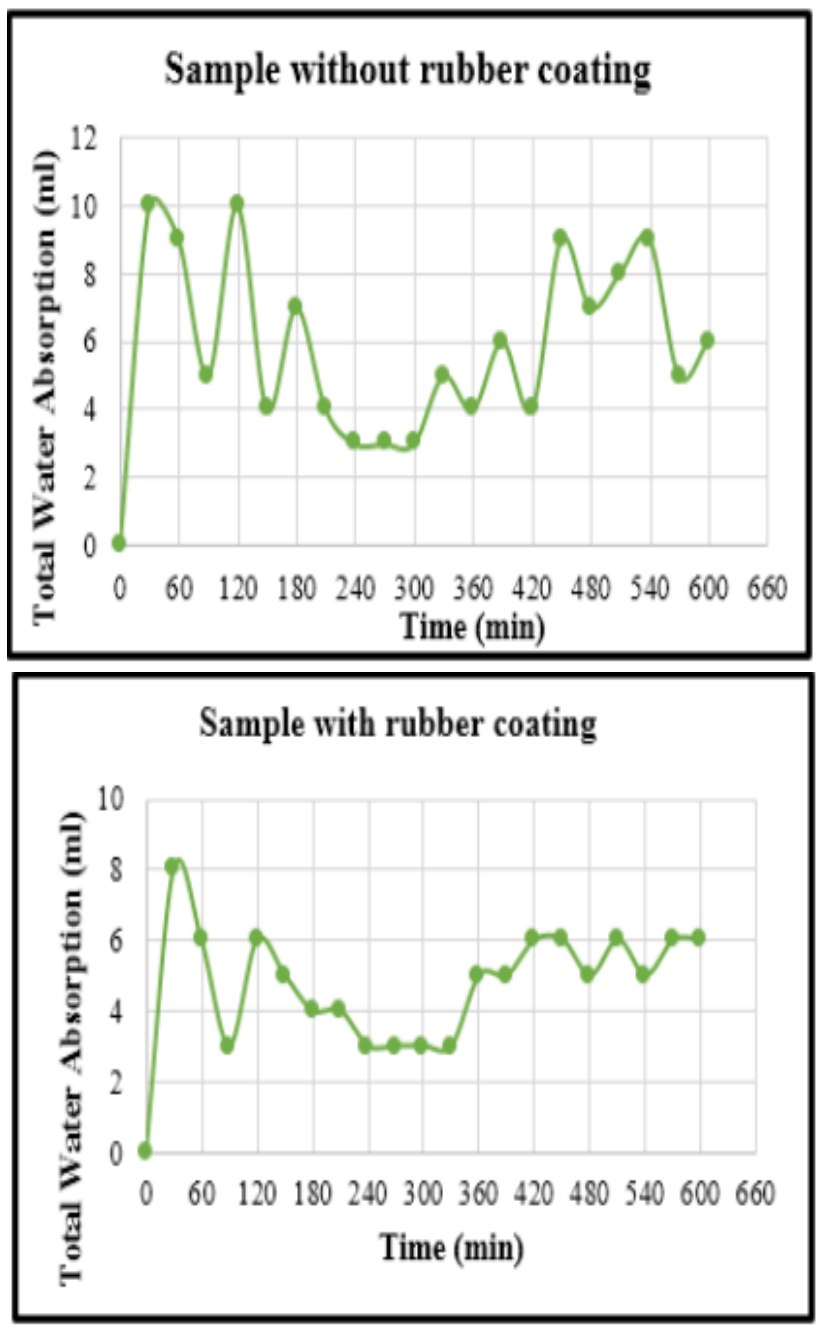

Fig. 6: Results from water absorption testing

After passing all the tests, Sample 5 is sent for production to making block toys. Figure 10 depicts the samples of toys (camera and car) created from the coconut coir/husk through the processes discussed earlier. 


\section{Conclusion}

The research has creatively transformed the coconut coir/husk into block toy compound by using natural materials through several processes. Nine samples were created using combination of several natural materials. Only two samples (Sample 5 and Sample 6) were found to be suitable for further testing before turning the end material into block toy. Through pressure resistance testing, Sample 5 came first and this was continued with other tests such as the termite resistance test and water resistance test. Sample 5 did not have problem with termite and Sample 5 with rubber coating has higher water resistance. Out of nine samples created, Sample 5 was found the most suitable processes to follow to produce the block toy compound as it takes only 20 minutes to form into a block; lightweight, soft and rubbery; no cracking problem and can be easily cut using knife. The unwanted coconut coir/husk can now be transformed into useful material for block thus may save the environment and create income to toy industry.

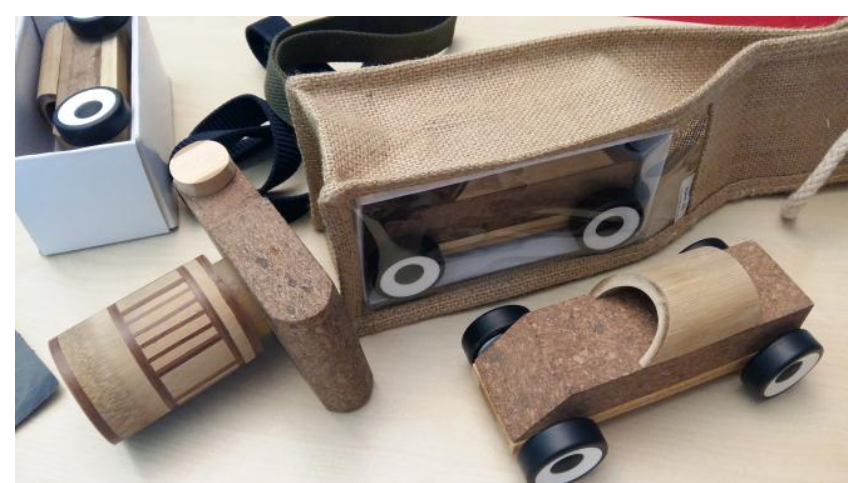

Fig. 7: Samples of products produced from coconut coir

\section{Acknowledgement}

This paper was derived from Myra Special Funding for Research Institutes/INDI UNIMAS, Grant No: I04/SpFRI/1431/16/8. The researcher would like to thank Borneo Coconut Fiber Sdn. Bhd, Asajaya, Sarawak, Haji Udin, Kampung Niup, Kota Samarahan, Sarawak, Mr Francis and Mr Fabian, Kampung Terbat, Serian, Sarawak.

\section{References}

[1] Persley GJ (1992), Replanting the tree of life: towards an international agenda for coconut palm research. 1st Edition. CABI

[2] Hasany MH, Ahmad R (2006), The potential of cost-effective coconut husk for the removal of toxic metal ions for environmental protection. Journal of Environmental Management 81(3), November, 286-295.

[3] Sri Chandrabakty B, Alfriansyah R, Tahir M (2014). Pengaruh linkungan komposit serat sabut kelapa untuk aplikasi baling kincir angin. Jurnal Mekanikal 5(1), Jan, 448-454.

[4] Kavitha M (2015), Production process of coir and coir products International Journal of Research in Business Management 3(3), Mar, 39-48.

[5] Shanmugasundaram R, Jeyalakshmi T, Sweatha S, Mohan M, Saravanan A, Goparaju P, Murthy B (2014), Coco peat an alternative artificial soil ingredient for the earthworm toxicity testing. Journal of Toxicology and Environmental Health Sciences 6(1), 5-12.

[6] Ganiron Jr GU (2013), Investigation on the use of coco coir polypropylene as thermal insulator. International Journal of Advanced Science and Technology 59,13-26.

[7] Othman MH, Main NM, Kunchi SZ, Mohamad Z (2013), Development of paper using coir fibers as a packaging product. Asian Journal of Scientific Research 6, 207-216. 